\title{
Immobilization of Proteins in Poly-Styrene-Divinylbenzene Matrices: Functional Properties and Applications
}

\author{
Rafael C. Rodrigues ${ }^{1}$, Karel Hernandez ${ }^{2,3}$, Oveimar Barbosa ${ }^{2,4}$, Nazzoly Rueda ${ }^{4}$, Cristina Garcia-Galan ${ }^{2}$, Jose \\ C. S. dos Santos ${ }^{2,5}$, Angel Berenguer-Murcia ${ }^{6}$ and Roberto Fernandez-Lafuente ${ }^{2 *}$
}

\begin{abstract}
${ }^{I}$ Biotechnology, Bioprocess and Biocatalysis Group, Institute of Food Science and Technology, Federal University of Rio Grande do Sul, Av. Bento Gonçalves, 9500, P.O. Box 15090, ZC 91501-970, Porto Alegre, RS, Brazil; ${ }^{2}$ Departamento de Biocatalisis. ICP-CSIC. Campus UAM-CSIC. Cantoblanco. 28049 Madrid. Spain; ${ }^{3}$ Permanent address: Biotransformation and Bioactive Molecules Group. Instituto de Química Avanzada de Cataluña-CSIC Jordi Girona 18-26, 08034. Barcelona, Spain; ${ }^{4}$ Permanent address: Escuela de Química, Grupo de investigación en Bioquímica y Microbiología (GIBIM), Edificio Camilo Torres 210, Universidad Industrial de Santander, Bucaramanga, Colombia; ${ }^{5}$ Permanent address: Departamento de Engenharia Química, Universidade Federal Do Ceará, Campus Do Pici, CEP 60455-760, Fortaleza, CE, Brazil; ${ }^{6}$ Instituto Universitario de Materiales, Departamento de Química Inorgánica, Universidad de Alicante, Campus de San Vicente del Raspeig, Ap. 99 - 03080 Alicante, Spain
\end{abstract}

\begin{abstract}
Supports based on poly-styrene-divinylbenzene (PSD) are commercially available since a long time ago. However, they are not commonly used as enzyme immobilization matrices. The main reason for this lies in the negative effect of the very hydrophobic surface on enzyme stability that produces the instantaneous enzyme inactivation in many instances. However, they have recently regained some impact on enzyme immobilization. They are easy to modify, and have been prepared with different modifiers. We will pay special attention to the coating of these supports with ionic liquids, which permits to have the ionic liquid phase anchored to the solid and modulate the enzyme properties without risk of losing these expensive and potentially toxic compounds. Thus, this review will present the covalent or physical immobilization of enzymes on PSD supports, submitted to different modifications. Moreover, lipases immobilized via interfacial activation on some naked PSD supports have shown some unexpected improvement in their catalytic properties, with uses in reactions like hydrolysis, esterification or transesterification.
\end{abstract}

Keywords: Hydrophobic supports, enzyme destabilization, interfacial activation of lipases, modulation of lipase properties, supported ionic liquids.

\section{INTRODUCTION}

Enzyme immobilization is a requirement in many cases to use enzymes at industrial level, as this solves the problem of enzyme solubility in the reaction media and facilitates its reuse [1-3]. However, enzyme immobilization is also a powerful tool to improve enzyme properties. A proper immobilization not only permits the easy separation of the enzyme from the reaction media to reuse it, but it has also been used to improve some enzyme properties, like stability, activity, selectivity or specificity [4-6].

Generally, the preferred immobilization support should be one able to initially interact with the enzyme, but once the researcher has decided to stop the immobilization process, it may offer an enzyme surface as inert as possible to avoid uncontrolled enzyme/support interactions. That way, the researcher may "stop" the enzyme/support reaction and the support will not produce any unexpected effect on immobilized enzyme properties. In this sense, a very adequate support may be agarose activated with glyoxyl groups, the support is highly hydrophilic, and the reactive groups may be easily reverted to inert hydroxyl groups by a reduction [7, 8]. However, some immobilization protocols, due to their immobilization mechanism, may not produce a final inert surface. This

*Address correspondence to this author at the Departamento de Biocatálisis. Instituto de Catálisis-CSIC, C/ Marie Curie 2. Campus UAM-CSIC. Cantoblanco. 28049 Madrid, Spain; Tel: --------------; Fax: -----------------; E-mail: rfl@ icp.csic.es involves most of the ones that immobilize enzymes via physical adsorptions: generally a multipoint immobilization process is required to fix the enzyme to the support (e.g., ion exchangers), and that means that the support must have a high activation degree [9]. That way, the immobilized enzyme may interact with the support during storage or operation.

In this context, hydrophobic supports have been recognized as very negative for the enzyme stability, because these uncontrolled enzyme-support interactions may play a negative role in the enzyme stability. Proteins generally have the hydrophilic groups on its surface, while hydrophobic groups will be inside the protein core. However, the groups in a protein are in continuous movement, and the hydrophobic groups can reversibly go outside by small fractions of time. If these hydrophobic pockets interact with a hydrophobic surface, this denatured conformation of the enzyme may be stabilized, and the protein becomes inactivated. Thus, immobilization on very hydrophobic support does not seem recommended from the point of view of enzyme stability (Fig. 1).

However, there are some cases where this high hydrophobicity becomes an advantage for the operational biocatalyst stability that could compensate the general drawback. For instance, in certain cases, the immobilized enzyme is used in organic medium, and it is inactivated under operation due to the accumulation of hydrophilic compounds in the surroundings of the enzyme environment (e.g., water, glycerin, short chain carboxylic acids, etc.). This occurs, for example, in the production of biodiesel or esterification reactions 


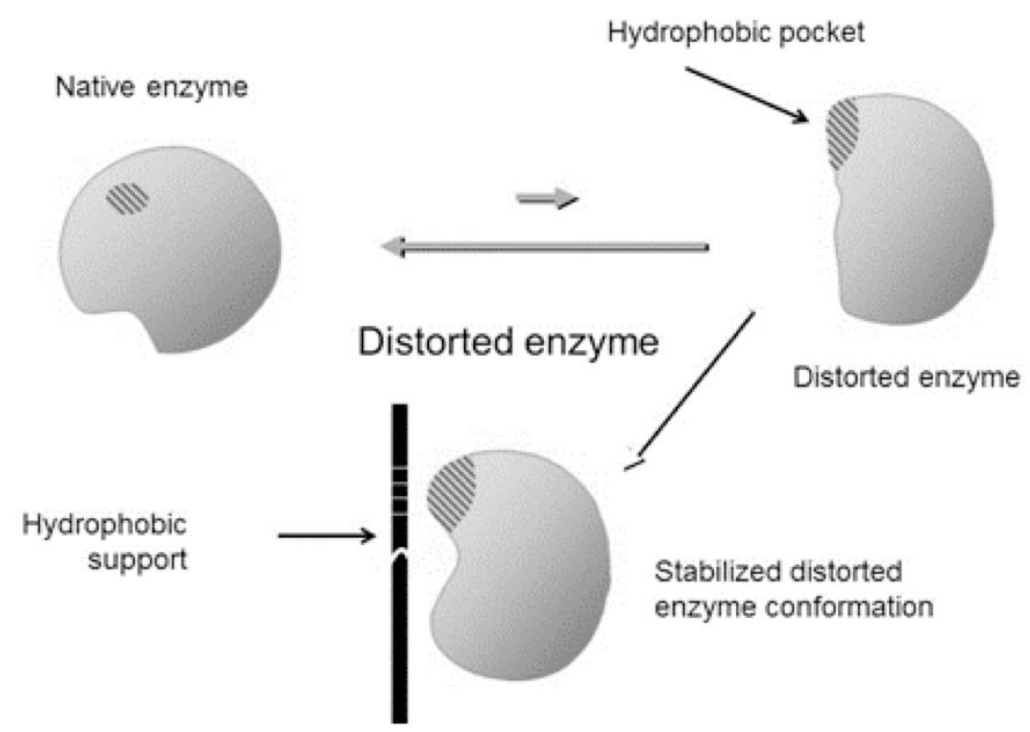

Fig. (1). Enzyme inactivation caused by interaction with hydrophobic interfaces.

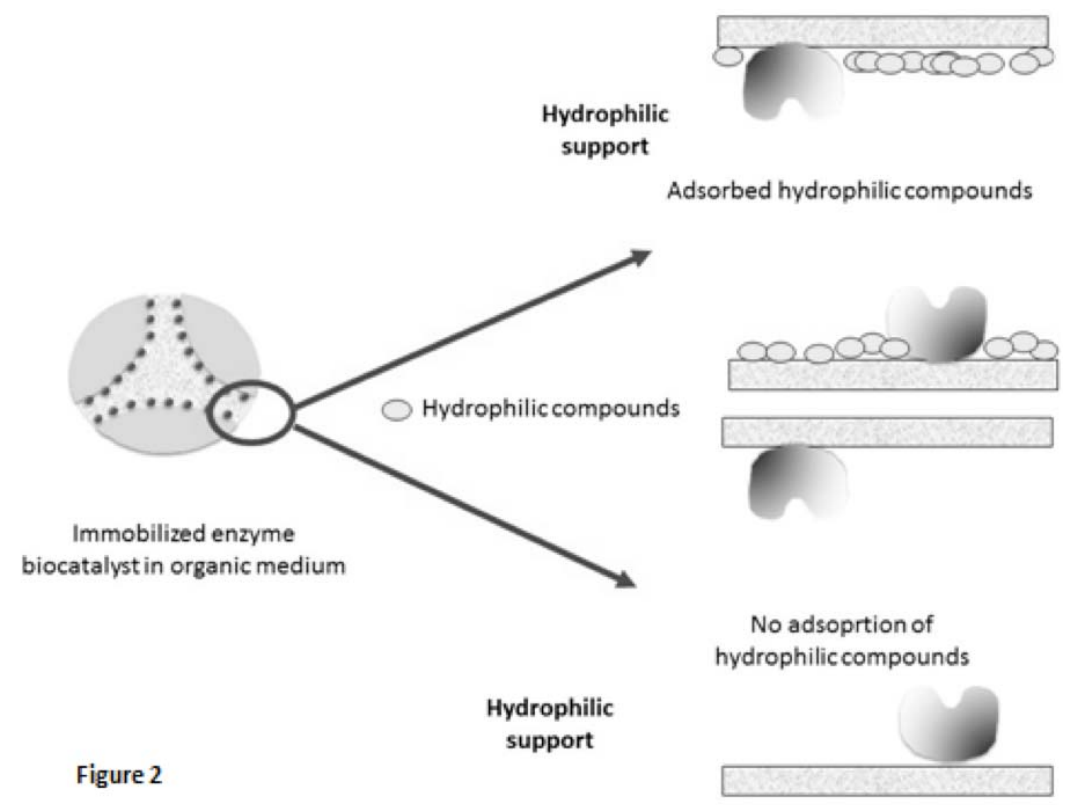

Fig. (2). Enzyme inactivation in organic media caused by hydrophilic compounds retained by the support. Advantage of using a hydrophobic support.

[10-12]. Thus, the use of a very hydrophobic support may reduce and even eliminate this problem [13], compensating a decrease in the enzyme thermostability (Fig. 2).

Similarly, hydrogen peroxide is a highly reactive compound that can rapidly inactivate an enzyme [14]. A very hydrophobic support may permit to produce a partition effect, reducing the concentration of this negative reagent on the area of the protein near to the hydrophobic support surface, and producing a significant stabilization of the enzyme (Fig. 3).

Thus, although a very hydrophobic support may not be the best option considering the enzyme stability, in certain cases it may become a possibility to solve a problem that can inactivate an immobilized enzyme in a more rapid way than the enzyme denaturation, improving its operational stability. In this review, we will focus on poly styrene-divinylbenzene supports, which is a very high hydrophobic matrix, even though other additional monomers may be also used in some instances.

\section{POLY-STYRENE-DIVINYLBENZENE MATRICES AS SUPPORTS TO IMMOBILIZE ENZYMES}

Poly-styrene-divinylbenzene (PSD) supports are produced by the copolymerization of styrene using divinylbenzene as crosslinking reagent. Divinylbenzene has been used as crosslinker of many other polymeric matrices, like different acrylates, giving supports with a lower hydrophobicity [15-18].

PSD may be modified during preparation, and it is possible to find beads or membranes of poly-styrene-divinylbenzene with an ionic substituent. Depending on the exact preparation protocol, its nature and internal morphology may differ. In general, the unmodified support is a very hydrophobic material that can suffer problems to permit the entry of water on their pores.

The very hydrophobic nature of PSD may permit an easy hydrophobic adsorption of proteins, like bovine serum albumin, and this has been used in certain cases to develop systems to quantify the immobilized enzyme on a matrix, without considering any 

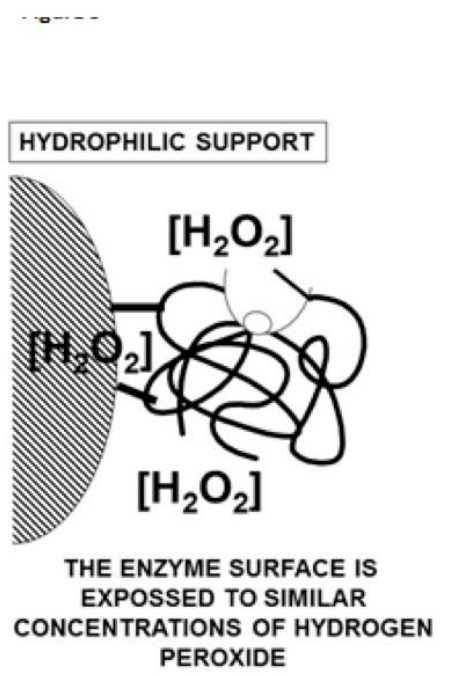

HYDROPHOBIC SUPPORT

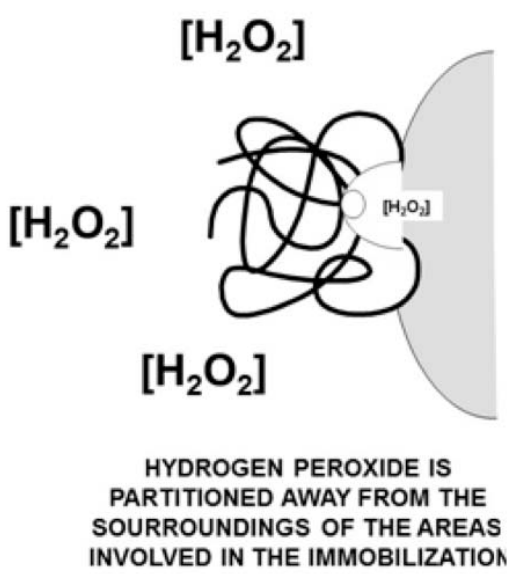

Fig. (3). Enzyme stabilization by hydrogen peroxide using hydrophobic supports.
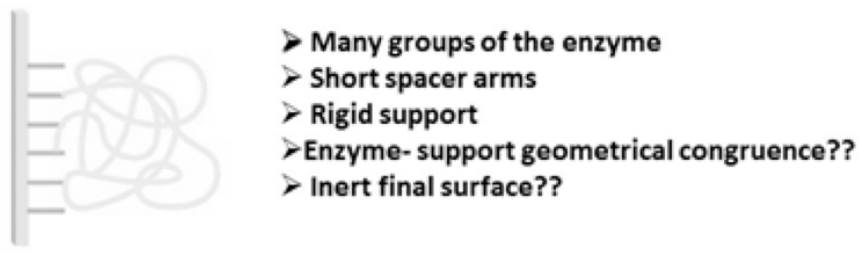

All relative positions must remain unaltered under any distorting condition

\section{Multipoint covalent attahcment}

Fig. (4). Enzyme stabilization via multipoint covalent attachment.

negative effect of the immobilization on the hydrophobic support on the enzyme structure. For example, particle mass spectrometry has been used to characterize the protein adsorption on microparticles based on the mass variations before and after protein adsorption [19]. This hydrophobicity has been reduced in certain cases, even having supports with very limited adsorption of proteins, by modification with polyethylene glycol. This was the case of the coating of PSD supports, with magnetite to have a magnetic nanoparticle, that was later aminated and finally modified with PEG: the new beads marginally adsorbed bovine serum albumin [20].

Nevertheless, this support has been in certain cases successfully applied in the immobilization and use of some catalytically active enzymes. Next, we will try to present some examples of the drawbacks and advantages of these supports to immobilize different enzymes.

\subsection{Immobilization of Enzymes via Covalent Attachment}

The immobilization via covalent attachment has several advantages compared to physical adsorption, e.g., there is no risk of enzyme desorption under any reaction media, stabilization may be achieved via multipoint covalent attachment [4] (Fig. 4). However, it also presents some drawbacks, like that immobilization usually is an irreversible process, and the support must be discarded once the enzyme is inactivated, and the immobilization protocols tend to be more sophisticated (usually are multistep) [4] . Thus, this immobili- zation strategy did not seem very adequate to immobilize proteins if the immobilization did not introduce some clear advantages on the enzyme properties (usually, stabilization) [5].

PSD hydrophobicity makes this support not recommended for immobilization of enzymes via covalent attachment, and in fact, this support is not very popular on these uses even though there are many different ones that have been commercially available for a long time. The problems generated by the hydrophobicity have been studied in a systematic way in several cases. For example, the comparison of PSD with other styrene crosslinked polymers (that offer a lower hydrophobicity like ethylene glycol dimethacrylate, 1,4-butanediol dimethacrylate and ethylene glycol acrylate) produced an improvement on the expressed activity of catalase covalently attached to carboxylated supports [21]. An inverse correlation between hydrophobicity and activity retention was found in this study. In a similar study, divinylbenzene was used to crosslink polystyrene and the more polar polyacrylamide, while styrene was crosslinked with diverse reagents (e.g., divinylbenzene, tetraethyleneglycol) [22]. Papain was immobilized on these polymeric supports and used for the synthesis of peptides in aqueous-organic solvent mixtures. A decrease in the support hydrophobicity invariably resulted in an increase in the yield of the peptide synthesis.

However, PSD supports have been used in some cases with relatively good results. Glutaraldehyde has been use in many instances to get the covalent immobilization of enzymes on different supports, or just to crosslink physically adsorb proteins. This rea- 
gent has a great potential in biocatalysis to prepare catalysts with an intense multipoint covalent attachment, and also may introduce inter or intra crosslinkings that can produce positive effects on enzyme stability [23]. Using PSD, in some cases aminated supports were treated with glutaraldehyde to get an activated support, in other cases polyglutaraldehyde was part of the polymerization suspension.

Lipases may be the most widely used enzymes in the field of biocatalysis $[1,[1,24,25]$ and for this reason, many of the examples of immobilization on PSD activated with glutaraldehyde are lipases. Most of the researches have been performed using the lipase from Thermomyces lanuginosus, one of the most used and stable lipases [26].

Polyglutaraldehyde-activated poly(styrene-divinylbenzene) has been employed to immobilize the lipase from T. lanuginosus with $85 \%$ yield [27]. The immobilized enzyme retained full activity after 30 days storage under open bench conditions and retained its full activity during the 15 batches of replicated biodiesel syntheses. Later the same groups used this biocatalyst to produce biodiesel using methanol and canola oil (97\% yield in $24 \mathrm{~h}$ of reaction) [28]. Comparing the use of PSD and PSD-activated with polyglutaraldehyde, immobilization yield improved from $60 \%$ to $85 \%$

In a further study, they used this support in the form of powder, beads, and monoliths [29]. Immobilized lipase was satisfactorily used for the synthesis of biodiesel using sunflower, soybean, and waste cooking oils. tThe results indicated that immobilized enzymes retain their original activities for 10 repeated batch reactions at $25^{\circ} \mathrm{C}$, each one of them lasting $24 \mathrm{~h}$.

The immobilization of this lipase on a similar support was optimized by response surface methodology in order to comprehend the reach and relevance of the factors influencing the specific activity of the immobilized lipase [30]. Different effects (enzyme concentration (ranging from 4-16\%, v/v), $\mathrm{pH}$ (6.0-8.0), buffer concentration $(20-100 \mathrm{mM})$ and immobilization time $(8-40 . \mathrm{h}))$ were analyzed in this respect. The results showed that the first three factors were significant on the specific activity of the immobilized lipase. A $12 \%$ activity decrease was detected after 10 cycles of biodiesel production ( $24 \mathrm{~h}$ each batch) from methanol and canola oil. The immobilized lipase was almost fully stable in tert-butanol (92\%) whereas it lost most of its activity in methanol (80\%) after 15 min of incubation.

In another research, three different lipases compounds (from Aspergillus oryzae and Lipozyme TL-100L ${ }^{\circledR}$ and Novozym $388^{\circledR}$ ) were immobilized on PSD naked and activated with glutaraldehyde, andused to produce biodiesel, being lipase from T. lanuginosus the most effective [31]. Lipozyme TL-100L ${ }^{\circledR}$ immobilized on glutaraldehyde activated PSD resulted in the production of fatty acid methyl esters to a yield up to92\%. A small enzyme deactivation was observed after 10 batches and the enzyme remained linked to the polymer the polymer,

In another example, this enzyme immobilized on styrenedivinylbenzene polyglutaraldehyde copolymer was successfully employed for the synthesis of biodiesel using methanol and pomace oil [32]. The maximum yield in methyl esters production was $98 \%$.

In another paper, the utilized lipase was that from Rhizomucor miehei, also a frequently utilized enzyme in biocatalysis [33, 34]. In this case, hairy poly(styrene-glycidylmethacrylate) brushes were prepared by grafting using bromoacetylated poly(styrene- divinylbenzene) microspheres as starting compound via surface-initiated atom transfer radical polymerization [35]. Two different strategies for the covalent immobilization of lipase onto the aforementioned microspheres were adopted: (1) direct immobilization of the lipase on the polymer brushes by means of the epoxy groups, and (2) immobilization of lipase via coupling of the glutaraldehide moieties after modification of the epoxy group with hexamethylenediamine on the polymer brushes. Covalent immobilization of the lipase on microspheres after attachment of the spacer-arm and glutaraldehyde coupling proved the most effective binding method, perhaps because the epoxy function may react with many groups of the enzyme but with a slower rate than glutaraldehyde [23]. Thermal and storage stabilities increase upon immobilization.

The immobilized lipase was reused with great efficiency in successive runs in a solvent-free system for the synthesis of isoamyl acetate via esterification. Only $21 \%$ activity was lost after 10 successive cycles [35].

Horseradish peroxidase is another enzyme that has been immobilized in some instances using this support and chemistry. It has been immobilized on styrene-divinylbenzene-polyglutaraldehyde supports, with $90 \%$ efficiency under optimum immobilization conditions [36]. This biocatalyst was successfully employed for the determination of the total phenolic content of four different Prunella $L$. species. This enzyme was also immobilized on PSD functionalized with triglycine and activated with 1l'carbonyldiimidazol with almost a $100 \%$ yield and with no apparent loss of enzymatic activity [37]. This biocatalyst was successfully used to decontaminate artificially contaminated waters containing phenol, 2-methoxyphenol or 3-chlorophenol, with a removal of the contaminants ranging 75 to $100 \%$. In another paper, the enzyme immobilized on microporous poly(styrene-divinylbenzenepolyglutaraldehyde) monoliths to develop a colorimetric detection for phenol biosensing [38]. The microarchitectured sstructure of the monolith improved mass-transferring for the enzymatic reaction due to the flow which forcibly had to go through the micropores. The detection system showed a satisfactory accuracy and retained $60 \%$ of its initial signal for a time interval of almost two months.

In another example, horseradish peroxidase immobilized on styrene-divinylbenzene- polyglutaraldehyde was employed to determine the phenol content of different raspberry and blackberry cultivars [39].

Moreover, other enzymes have been subjected to immobilization on these supports. Ureases from watermelon seeds and from Staphylococcus saprophyticus were stabilized after immobilization of the enzymes on aminated supports activated with glutaraldehyde [40]. These supports have a reduced hydrophobicity (the amino and glutaraldehyde groups will reduce the hydrophobicity) while the prevention of enzyme dissociation could explain to some degree the stabilization effects found [41].

Glucoamylase and invertase were immobilized on a macroporous aminomethyl polystyrene-divinylbenzene copolymer using the glutaraldehyde route, and the stability and behavior in the presence of water-miscible organic solvents was analyzed [42]. The immobilized enzymes showed an improved long-term stability compared to their soluble counterparts.

Other strategies for the covalent immobilization of enzymes have been utilized, although only some few examples may be found.

Invertase was bound on three types of aminated solid supports (all of the by covalent bonds): glycidyl methacrylate, styrenedivinylbenzene copolymers, and cellulose beads after periodate oxidation of its glycosidic component [43]. The most active conju- 


\section{IMMOBILIZATION BY ADSORPTION}

- EASY IMMOBILIZATION PROTOCOLS

- THE SUPPORT MAY BE REUSED

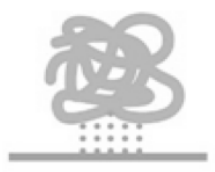

- RESIDUES REDUCTION

\section{RELEASE OF THE ENZYME DURING USE??}

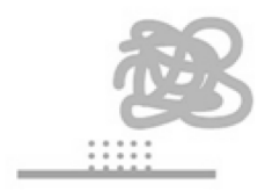

Fig. (5). Advantages and drawbacks of reversible enzyme immobilization.

\section{RAPID AND COMPLETE REACTIVATION}

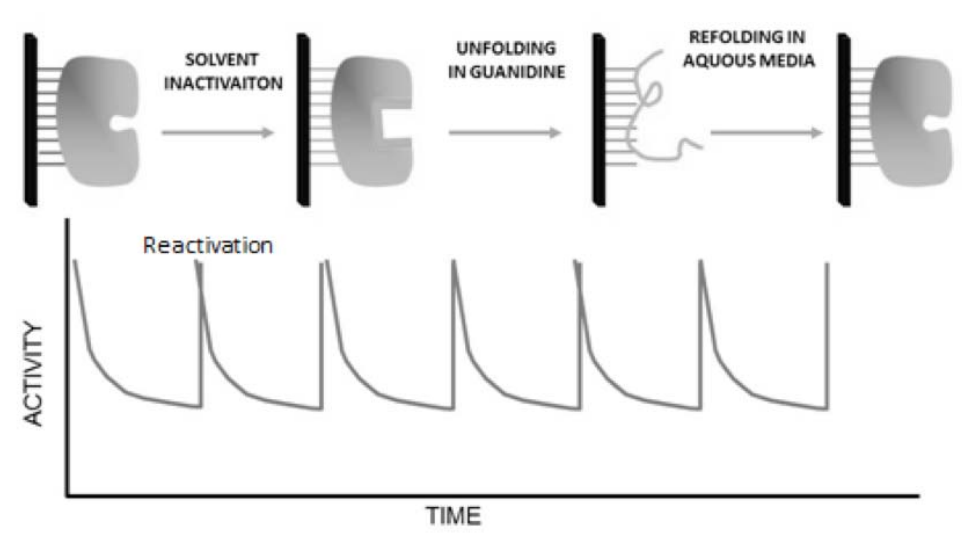

Fig. (6). Strategies of enzyme reactivation via unfolding/refolding strategies.

gate was obtained by the immobilization of oxidized invertase to a styrene-divinylbenzene copolymer.

Hydrophilic and macroporous polymer resins made up of of glycerylmethacrylate, styrene, and divinylbenzene were surfacemodified with isothiocyanate and used to covalently immobilize alkaline phosphatase and trypsin [44].

The immobilized enzymes were active and stable to a satisfactory degree, while the hydrophobic nature of PSD was reduced by the isothiocyanate groups. This polymer has been also used to coat magnetic nanoparticles. For example, poly(styrene/N-isopropylacrylamide/methacrylic acid) latex particles which contained ultrafine magnetite particles were prepared, and the crosslinking with divinylbenzene was found to play a positive role.

They improved the separation of thermo-flocculated latex particle using a magnet [45]. Porcine trypsin was immobilized covalently onto the magnetic latex particles with high efficiency using the carbodiimide moieties.

\subsection{Immobilization via Physical Adsorption}

The physical adsorption of proteins is the oldest strategy to immobilize proteins, e.g., ionic exchange, hydrophobic adsorption. This is a very simple strategy of immobilization, the supports are fully stable and may be stored for a long time before its use and, as main advantage, the support may be reused after releasing the inac- tivated protein [4]. However, there are some drawbacks. The enzyme cannot be used under conditions where the enzyme may become desorbed from the support $(\mathrm{pH}$ or ionic strength will be restricted in ionic exchange $[9,46,47]$, solvents or detergents in hydrophobic adsorptions, etc. [48]. Moreover, the enzyme may be released during operation, e.g., if changes in the $\mathrm{pH}$ occur (e.g., internal $\mathrm{pH}$ gradients may be formed during esters hydrolysis (Fig. 5). Furthermore, the support surface will never be "inert", and this can produce undesired enzyme supports/interactions during storage or use. This kind of immobilization may not be compatible with folding/unfolding reactivation strategies of enzymes: unfolding may produce enzyme release, whereas refolding will be affected by interactions with the support [4, 49-52] (Fig. 6). This immo-bilization strategy may have complex effects on enzyme stability (mainly generating enzyme environments) [4], although it may be useful to prevent enzyme dissociation, at least in the case of dimeric enzymes [41].

The hydrophobic nature of the support converts it in a good option for hydrophobic adsorption of enzymes. However, as explained above, a too high hydrophobicity may produce very negative effects on the enzyme activity/stability. However, there are some examples of using this hydrophobic supports. In a research, human fibrinogen was adsorbed in polystyrene-divinylbenzene microparticles [53]. When platelet-rich plasma was injected in a stirred suspension of fibrinogen-coated beads, the platelet aggregation rate was propor- 


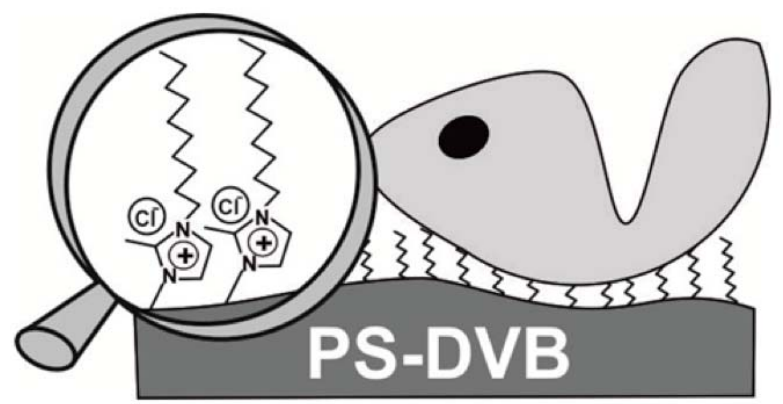

Fig. (7). Immobilization of enzymes on ionic liquids coated PSD-supports.

tional to the concentration of fibrinogen on the bead surface. The response was not mitigated by hirudin, indicating that any thrombin generated during the reaction did not participate in bead aggregation. Conversely, ReoPro completely hindered platelet aggregation, indicating specific fibrinogen- $\alpha \operatorname{IIb} \beta 3$ interactions as the ones responsible for the observed effect [53]. Those beads coated with either albumin or lecithin, did not coalesce under identical conditions, nor did fibrinogen-coated beads agglomerate when plateletdepleted plasma was injected. When the beads were coated with fibrinogen as a mixed film with lecithin, a striking increase in yield toward platelets was demonstrated (compared to unmodified beads). These observations indicated that the reported adhesion of platelets to the beads is a direct indication of platelet-fibrinogen interactions. Thus, platelets respond differently to fibrinogen when presented in this form, compared to the protein left alone at the interface [53].

In another paper, $\alpha$-glucosidase was produced in $S$. cerevisiae. After cell disruption, a non-ionic polystyrene-divinylbenzene (XAD-16) was tried to adsorb the enzyme, but the adsorption drove to the enzyme inactivation $[54,55]$. This was prevented modification of the surface of this support by grafting a few selected acrylate monomers by co-polymerisation, enabling a very good yield in the purification. The hydrophobic support has been also used to directly immobilize some cells. The white rot fungus (Phanerochaete chrysosporium) has been immobilized on porous poly(styrenedivinylbenzene) carriers and used for production (both in batch and repeated) of lignin peroxidase. This was performed in shake cultures based on a carbon-limited medium which contained veratryl alcohol [56]. The best results were obtained when a spore inoculum was used for immobilization instead of mycelial pellets aged for one day in both cases. The porous poly(styrene-divinylbenzene) immobilized Phanerochaete chrysosporium and suspended mycelial pellets in free media were used for the catalytic degradation of 2chlorophenol and the immobilized spores displayed a significantly enhanced activity in the degradation of 2-chlorophenol [56].

The introduction of ionic groups on the support surface permits to reduce its hydrophobicity and immobilize proteins via ionic exchange.

For example, PSD with various structures have been modified to introduce mobile halogen atoms and used to immobilize glucoamylase and pepsin [57]. The results indicated that the iodoacetylated derivatives of the styrene-divinylbenzene copolymers with a macroporous structure and high iodine loadings are the most suited for immobilization purposes.

Lysozyme has been immobilized on an anion exchanger polystyrene divinylbenzene matrix (Deacidite KMP), and in other supports. The immobilized enzyme has been used to lysate Micrococ- cus luteus, this preparation retained the higher activity (26.67\%), almost doubling the other preparations [58].

Papain has been anchored on amine modified polyethylene/poly(styrene-co- divinylbenzene) and polyethylene/poly-(vinylbenzyl chloride-co-divinylbenzene) membranes [59]. Three process variables were analyzed: concentration of papain in solution, time and temperature of sorption. Temperature was fund to insignificantly affect the immobilization.

Other paper shows how a polystyrene-divinylbenzene membrane was used as support for trypsin immobilization by electrostatic and hydrophobic interactions. This system was successfully applied for protein digestion [60]. Cytochrome C, myoglobin, and bovine serum albumin, were sed as performance monitors. The results showed that even for short digestion times (several seconds) the resulting sequence coverages was comparable to or higher than those found with in-solution digestion. This system was also applied for the analysis of proteins from yeast cell lysate. Cellulose has been immobilized on a modified PSD support. Poly(styrenedivinylbenzene) microspheres were anchored with polystyrene by surface initiated-atom transfer radical polymerization. The grafted polystyrene chains were sulfonated. The sulfonic acid groups found on the surface brushes were neutralized with aniline. The adsorbed aniline was polymerized by oxidation (using potassium persulfate) to give self-doped thick layers (i.e. $16 \mu \mathrm{m}$ ) on the microspheres [61]. Afterwards, cellulase was immobilized on the microspheres via adsorption and adsorption/crosslinking methods.

Upon immobilization, the activities of the adsorbed and adsorbed/ crosslinked cellulose for the recovered samples were 73 and $62 \%$ for carboxymethyl cellulose, respectively. The immobilized enzyme suspensions were more stable and retained their activities to a higher degree at drastic $\mathrm{pH}$ and temperature than those with the free enzyme.

\section{PDS COATED WITH IONIC LIQUIDS}

Ionic liquids have many advantages to be used as solvent in biocatalysis. The properties of ionic liquids (density, viscosity, polarity, melting point, etc.) can be fine-tuned by appropriate chemical screening. Their interest as green solvents lies in their high thermal stability and negligible vapor pressure, which paliates the problem of their emission to the atmosphere [62-64]. Ionic liquids are expensive compared with conventional solvents. Furthermore, some of them have low biodegradability and possible (eco)toxicological properties [65-67]. Thus, immobilization of ionic liquids on a support or structured material may be contemplated as workaround solution to minimize the amount of required ILs, while retaining their properties. On top of that, supported ionic liquids have the benefit of easy separation and recyclability as well as their potential use in continuous processes development [65-67]. Hence, the immobilization of ionic liquids onto a support or structured material is an attractive strategy to minimize the amount of ILs used, while maintaining their properties. Additionally, supported ionic liquids have the advantage of easy separation and recyclability as well as a potential for use in the development of continuous processes [68-71]. Thus, the immobilization of the ionic liquids on PSD supports is one of the proposed solutions. Figure 7 represents the interaction between enzyme, support and ionic liquid. The ionic liquids are covalently attached to the support, and their side chain, generally hydrophobic, is used to attach the enzymes to the PSDionic liquid matrix. 
Most examples of use of PSD coated with ionic liquids involve lipases. In an interesting paper, the combined action of microwave irradiation and lipase B from $C$. antarctica immobilized onto PSD coated with ionic liquids was analyzed in the resolution of rac-1phenylethanol using vinyl propionate [72]. This strategy produced a 28 -fold increase of the activity improvement, and the biocatalyst could be used for 12 cycles without significant activity decrease. The combination with an inorganic catalyst permitted the one -pot dynamic kinetic resolution of this compound.

In some cases, supercritical fluids have been used in some reactions, and the combined use with ionic liquids has some advantages, improving lipase performance in this system [73-75].

One pioneer example of the use of ionic liquids combined with supercritical fluids was demonstrated for the lipase B from C. antarctica [76]. The free and immobilized forms of the lipase were dispersed in different ionic liquids (1-ethyl-3-methylimidazolium bistriflimide and 1-butyl- 3-methylimidazolium bistriflimide). These systems were employed as biocatalyst for the kinetic resolution of rac- 1-phenylethanol in supercritical $\mathrm{CO}_{2}$ at $150^{\circ} \mathrm{C}$ and 10 MPa under a continuous regime. The enzyme showed excellent activity, stability and enantioselectivity under continuous operation [76].

This lipase was also used in bioreactors with ionic liquid phases which are covalenty attached. These are prepared as monoliths based on PDS coated with imidazolium [77]. The monoliths were able to absorb lipase B from $C$. antarctica. This biocatalyst was employed in the synthesis of citronellyl propionate under supercritical carbon dioxide by transesterification reaction. The activity of the immobilized enzyme remained practically unaltered after seven cycles lasting $5 \mathrm{~h}$ each, better than using other immobilized preparations of the same enzyme. These biocatalysts were more deeply characterized later, as well as the effect of the microwave heating [78].

In another example, different supports derived from 1-decyl-2methyimidazolium cations attached covalently to a porous matrix based PSD, were used as carriers to immobilize lipase B from C. antarctica [79]. The suitability of these immobilized lipase derivatives for the methanolysis of triolein was tested using tert-butanol or supercritical carbon dioxide as reaction media. The new supports led to highest reactions yields ( $85 \%$ biodiesel yield after 45 consecutive cycles of 8-4 h) in supercritical CO2. The addition of tertbutanol as inert co-solvent in the supercritical $\mathrm{CO} 2$ phase with the same concentration as triolein was the key to avoid that the produced glycerol inactive the biocatalyst [79].

Thus, PSD coated with ionic liquids seem to be one of the strongest current tendencies, due to the versatility, which is coupled to the versatility of ionic liquids.

\section{LIPASE IMMOBILIZATION VIA INTERFACIAL ACTI- VATION ON HYDROPHOBIC SUPPORTS}

We have left one exception to the problems of immobilization on hydrophobic supports via physical interactions: lipases [48]. These are peculiar enzymes, having as catalytic mechanism the socalled interfacial activation that allows them to act in drops of hydrophobic substrates, becoming adsorbed on the drops of insoluble substrates and act in the interface [80,81]. This is because the active center is surrounded by a large hydrophobic pocket that permits this adsorption [82, 83]. However, this pocket will make complex keeping the lipases soluble in aqueous media, and in most cases are closed by a mobile peptide chain, called lid. This chain has a hy- drophobic end that interacts with the hydrophobic area surrounding the active center and a hydrophilic face that interacts with the medium. The lid may be very small, as it is the case for lipase B from C. antarctica [84], or become very complex, such as the double lid detected in the lipase from Bacillus themocatenolatus [85]. The lid is moving, exposing or blocking the active center to the outer medium. When a hydrophobic surface is offered, the lipase becomes adsorbed via the very large hydrophobic zone formed by the lid and the surroundings of the active region, and the lipase becomes very strongly chemisorbed on the hydrophobic region (the so-called interfacial activation).

This tendency of lipases to become adsorbed on hydrophobic has been used to develop a strategy for the immobilization, purification and hyperactivation of lipases [86] . Even in certain cases, the immobilization via this technique permits the enzyme stabilization and the modulation of enzyme selectivity towards hydrophobic substrates [48].

Moreover, it has been reported that the hydrophobicity and internal morphology of the support may be used to tune enzyme properties [87].

In this regard, the high hydrophobicity of the PSD supports may even become a certain advantage to immobilize lipases. Thus, these supports have been very used with these enzymes. The immobilization of lipases on these supports may have diverse advantages, depending on the final application.

\subsection{Use of the PSD-lipase Biocatalysts in Hydrolysis Reactions}

The hydrophobic nature of these supports makes them not very recommended for reactions in aqueous medium, e.g., hydrolysis. However, some examples may be found in the literature where results using these supports were even better that those using apparently more adequate supports.

PSD microporous polymer supports has been used to immobilize the lipase from $C$. rugosa and the resulting system was used to hydrolyze triacylglycerides $[88,89]$. The amount of adsorbed lipase was high and the enzymatic reaction rate per lipase molecule was higher for the immobilized enzyme than for its free counterpart, perhaps by a partition of the substrate in the support, perhaps because the enzyme was in the open form, or perhaps because the micelles cannot penetrate the pores and the enzyme was free of the negative effects of the oil emulsioners [6].

Using the same enzyme, another report analyzed the effect of the adsorption medium on the biocatalyst performance, using an aqueous solution (with sodium phosphate buffer) and and organic solvent (heptane) [90]. The results were improved when the coupling was performed with heptane. The $\mathrm{pH}$ optimum was shifted towards alkaline region, while the maximum temperature was increased, and the thermal stability compared to the free enzyme was also significantly improved. Later, the enzyme immobilized on a home-made PSD was characterized [91]. Immobilization resulted in an increase in the optimum temperature for enzymatic activity and the thermal deactivation of enzyme was slowed down. However, the immobilized lipase on PSD retained a lower activity after the first stage deactivation compared to the soluble enzyme. This suggests a possible change in the conformation of enzyme molecule by immobilization. The use of polyvinylpyrrolidone significantly reduced the hydrophobic features of PSD particles synthesized by the multistep swelling and polymerization method which involves the use of polymeric porogens [92]. The results from lipase immobilization on these particles evidenced that this protocol may shield the 
hydrophobic groups on the particle surface thus reducing the efficiency of enzyme immobilization.

An extracellular lipase of Pseudozyma hubeiensis (strain HB85A) was immobilized by adsorption onto a PSD support [93]. The optimal $\mathrm{pH}$ for hydrolytic activity was $\mathrm{pH} 4.6$ and 6.0 for the free and immobilized lipase respectively. Lipase immobilization resulted in improved enzyme stability under a wide variety of conditions (in the presence of nonionic detergents, at high temperatures, at acidic and neutral $\mathrm{pH}$, and at high concentrations of organic solvents (2-propanol, methanol or acetone)).

In another report, two commercial polymeric beads (Diaion HP20LX and MCI GEL CHP20P) were evaluated as supports to anchor lipase B from C. Antarctica [94]. Both supports were similar in texture following supplier descriptions, but their properties as supports to immobilize this enzyme were quite different, being the best results those obtained using MCI GEL CHP20P. This support immobilized the enzyme rapidly, allowing for a very high loading capacity(110 mg CALB/wet g of support versus $50 \mathrm{mg}$ obtained using octadecyl Sepabeads), a support previously reported as very suitable for this process [95]. The specific activities of the enzyme immobilized on MCI GEL CHP20P in hydrolytic reactions were always superior to those found using octadecyl Sepabeads for all tested substrates. In this respect, a CALB biocatalyst having 3-8 folds (the exact figure depending on the substrate) higher activity per wet gram of support than the commercial Novozym 435 has been obtained [94]. However, the thermal-stability of the resulting immobilized enzyme on this novel support was lower than its conventional counterpart of Novozym 435. The situation reversed in the presence of organic solvents, where this new preparation became the most stable [94]. Very recently the use of MCI GEL CHP20P has been reported to immobilize the lipases from T. lanuginusus and R. miehei, and also the artificial chimeric phospholipase Lecitase Ultra [96]. Again, the immobilization rate and yield were higher using this support than the standard one used for comparison (in this case octyl-agarose) [86], reaching values as high as 200 $\mathrm{mg} / \mathrm{ml}$ of packed wet support. The resulting thermal stability greatly decreased, while the stability versus organic solvents was greatly increased. The effect of the immobilization on this support on the hydrolytic activities greatly depended on the substrate and enzyme, in some cases the octyl-Sepharose lipases were 100 fold more active than the new one, in other cases the opposite were observed [96].

Thus, although these hydrophobic supports have main interest in organic media, many examples of the use of lipases immobilized on them in aqueous medium may be found in the literature.

\subsection{Use of the PSD-lipase Biocatalysts in Production of Bio- diesel}

Nowadays, the production of biodiesel using biodiesel is one of the main areas of research [97]. The use of lipases may permit to produce biodiesel from any kind of oil, under environmentally favorable conditions, and with high quality glycerin as sub-product [98]. However, glycerin is one of the main problems, as it becomes accumulated on the biocatalyst and finally avoids the hydrophobic substrates to reach the enzyme, also producing enzyme inactivation. In a recent paper, it was shown that the use of polystyrene supports avoids this glycerin issue due to the hydrophobic nature of the support [10]. This is even more pronounced on PSD, which is even more hydrophobic. Two different immobilized samples of lipase B from C. antarctica, commercial Novozym 435 and lipase immobilized on styrene- divinylbenzene beads (MCI GEL CHP20P) were screened for the synthesis of methyl esters from fatty acids using soybean oil and methanol [99]. Both biocatalysts showed markedly different optimal conditions in the reaction For Novozym -435 , optima conditions were 5.6:1 molar ratio methanol:oil, $25 \%$ enzyme (regarding the oil weight), and $5.44 \%$ of added water, while for the PSD immobilized lipase, the optimal conditions were 3:1 molar ratio methanol:oil, $25 \%$ enzyme, and $1.18 \%$ of added water. The PSD preparation presented more than $10 \%$ improved activity enabling conversions of more than $99 \%$ after $72 \mathrm{~h}$ of reaction under optimum conditions. Moreover, $70 \%$ of the initial activity was maintained after eight batches [99].

\subsection{Use of the PSD-lipase Biocatalysts in Esterification Reactions}

The enzymatic synthesis of short chain esters permits to label the esters as green product, and their market values as fragrance in food greatly increases. This makes that a great undertaking is being performed in the enzymatic production of flavor esters. The use of a very hydrophobic support has a double advantage: it reduces the concentration of short carboxylic acids on the enzyme environment, and reduces the retention of the formed water in the enzyme neighbor, two of the problems of these processes. In fact, there are many examples of using of lipases immobilized on PSD in this kind of processes.

Lipase from C. rugosa was immobilized onto PSD support and used in organic solvent containing butyric acid and butanol [100]. Heptane was selected as solvent due to its compatibility with both resin and enzyme. The results were compared with those of the free lipase and Lipozyme (commercially immobilized lipase) under the same operational conditions, showing that the immobilization on PSD greatly improved the enzyme performance.

Lipase from C. rugosa was immobilized in the presence of heptane on PSD and used to esterify $n$-butanol and butyric acid [90]. The tests performed to assess the operational stability of the samples indicated that after 12 consecutive batches ( $24 \mathrm{~h}$ per batch) a small enzyme deactivation occurs. Such results revealed good recycling potential in non-aqueous system.

Later, the same enzyme and reaction was performed using another PSD support [101]. Under optimal conditions, a yield of $75 \%$ was obtained (concentration of $32.4 \mathrm{~g}$ butyl butyrate/L of suspension that corresponds to a yield of $75 \%$ was obtained, after response surface methodology optimization. In a further study, using a solvent free system, the biocatalyst was compared to the enzyme immobilized on controlled pore silica and to Novozym 435 [102]. Using PDS, conversion was higher (63\%) using $10 \%$ of immobilized enzyme and lauric acid, (productivity of $3.62 \mathrm{~g} \mathrm{~L}-1 \mathrm{~h}-1$ ).

In another paper, fibrous polymeric brushes were grafted on poly(styrene-divinylbenzene) beads using surface-initiated atom transfer radical polymerization. To this samples tetraethyldiethylenetriamine ligand was incorporated [103].

The resulting beads were used for the reversible immobilization of the lipasefrom Mucor miehei. The thermal and storage stabilities of the immobilized lipase were enhanced compared to the original lipase. The same support could be used several times for the immobilization of lipases after its regeneration without significant loss in adsorption capacity or enzyme activity. The biocatalyst was successfully utilized to catalyze the direct esterification of butyl alcohol and butyric acid [103]. In some cases, long chain ester were produced by Candida sp. 99-125 lipase immobilized on PSD supports [104]. After immobilization, the thermal stability of the lipase was enhanced in the temperature range $30-50{ }^{\circ} \mathrm{C}$, and its stability in 
the $\mathrm{pH}$ range 6.0-9.0 was also increased. The esterification reaction of cetyl alcohol and oleic acid was efficiently catalyzed by the enzyme preparation with the yield of ester being $98 \%$. Operational stability tests indicated that the ester yield was still as high as $50 \%$ after 15 batch cycles.

Recently, a large activity on this kind of reactions has been performed using MCI GEL CHP20P, a commercially available PSD support $[94,96]$. In a first report lipase B from $C$. antarctica, immobilized on MCI GEL CHP20P was compared with the commercial Novozym 435 as biocatalysts for the esterification of acetic acid and n-butanol [13]. Lipase immobilized on MCI GEL CHP20P could be used under more acidic conditions, up to $0.5 \mathrm{M}$, while Novozym 435 became inactivated under these conditions. Although Novozym 435 exhibited higher initial activity than MCI-CALB (30\%) for the butyl acetate synthesis, the reaction course was more straighforward with new preparation, implying higher productivities per cycle for MCI-CALB. [13]. The primeval advantage of the new biocatalyst is its superior performance in its recycling. While Novozym 435 was fully inactivated after two runs, MCI-CALB can reused for six consecutive cycles without washings retaining $70 \%$ of its initial activity.

Later, both biocatalysts were tested in the synthesis of ethyl butyrate [105]. The lipase immobilized on MCI GEL CHP20P presented higher productivities (1.6 times) than Novozym 435. As in previous cases, the main advantage of the new support was related to its operational stability.

The new biocatalyst retained $80 \%$ of its initial activity after eight runs, while Novozym 435 retained only $20 \%$. T. lanuginosus lipase was also immobilized also in MCI GEL CHP20P, and compared to the commercial lipase Lipozyme TL-IM as catalyst in the synthesis of butyl butyrate [106]. The MCI GEL CHP20P immobilized enzyme displayed high initial reaction rates (up to butyric acid concentration $1.0 \mathrm{M}$ ), while Lipozyme TL-IM decreased in its activity above $0.5 \mathrm{M}$ of acid. Moreover, MCI-TLL presented a productivity of $14.5 \mathrm{mmolg}-1 \mathrm{~h}-1$ per mass of biocatalyst, while Lipozyme TL-IM $3.2 \mathrm{mmol}$ g- 1h-1.

In another paper, lipase from Staphylococcus warneri EX17 was purified and immobilized on hydrophobic octyl-Sepharose, Immobead 150, and MCI GEL CHP20P [107]. The resulting preparations on octyl- Sepharose and MCI GEL CHP20P were stable in the presence of several organic solvents. Containing only $8 \mathrm{mg}$ of enzyme per $g$ of support, the PSD preparation was a $25 \%$ more active than that immobilized on octyl-Sepharose in the generation of ethyl butyrate.

\subsection{Use of the PSD-lipase Biocatalysts in Promiscuous Reac- tions}

Lipases are able to catalyze many reactions that are quite far from the natural esterase function of the lipases, that is the so-called promiscuous activities of the lipases [108].

One of the promiscuous activities of lipases is the perhydrolysis of esters, the main problem of these reactions being the inactivation caused by the hydrogen peroxide via multiple chemical modification of the enzyme backbone [14]. Immobilization of lipase B from C. antarctica on hydropbobic octadecyl Sepabeads permitted to increase enzyme stability versus hydrogen peroxide, and that was explained by some partition of this dangerous reagent from the areas involved in the adsorption [109]. This effect was increased when the support was the more hydrophobic MCI GEL CHP20P PSD support. The lipase stability was 100 -fold higher in the presence of high concentrations of hydrogen peroxide $(10 \mathrm{M})$ [94]. This biocatalyst seemed to have good prospects to catalyze this kind of reactions.

In another example, the previous biocatalyst was compared with the commercial sample (Novozym 435) in as promiscuous catalyst of C-C bond formation [110]. ctivity increases when compared to the soluble form or with Novozym 435 (up to 6-fold more active). The observations show that even though this data is not related to the catalytic group, the activity of CALB may be altered by immobilization. The paper shows that the secondary structure is quite different for the immobilized enzymes, as evidenced with FTATR-IR spectroscopy [110].

Thus, lipase immobilization on PSD supports may also offer some advantages even in promiscuous activities, even if that is not related to the active center of the enzyme.

\section{CONCLUSIONS}

The interest on PSD supports has greatly increased along the last years. Although their hydrophobicity may be a problem for enzyme stability, in certain cases, the coating of their surface with different reagents can be used to mitigate this deleterious effect. The coating with ionic liquids holds special interest, since it permits to have the solid phase use of a "media" that have shown to have great prospects in Biocatalysis, easing their recovery, and still with power to modulate the enzyme properties and produce ionic liquid phase advantages.

The mechanical resistance of these polymers may be increased by increasing the crosslinking degree, the final biocatalysts may be mechanically as useful as any other of the organic polymeric supports currently used in the industry.

Immobilizing standard proteins, the high hydrophobicity of the surface is a problem because it can inactivate the enzymes and at least will reduce the stability. It is in the immobilization of lipases where PSD supports have found a higher relevance, as the interfacial activation of the lipases on their hydrophobic surface have permitted the strong immobilization, and also the partition of some deleterious compounds (e.g., hydrogen peroxide) away from the enzyme environment.

This hydrophobicity asserts that these kind of supports may be not recommended as adsorbents (e.g., to immobilized antibodies as an immune-sensor). The main interest will lay on the side of the biocatalysis.

A likely application of these hydrophobic supports, still to be reported is the one-step immobilization-purification of chimeric proteins bearing hydrophobic tags, some papers show how using hydrophobic supports, these tagged enzymes may be selectively immobilized [111-113]. These proteins should have a large affinity for these hydrophobic supports. However, these tags may have some impact on the enzyme performance: stability or tendency to aggregation may be a common problem.

However, it is still necessary to perform systematic studies on different PSD supports having controlled and well characterized internal geometry, hydrophobicity without changing the chemical composition, crosslinking degree, etc. Very likely, the knowledge of how these variables affect the PSD supports as enzyme immobilization matrix may permit a further expansion of these matrices as enzyme supports.

\section{CONFLICT OF INTEREST}

The authors confirm that this article content has no conflict of interest. 


\section{ACKNOWLEDGEMENTS}

We gratefully recognize the support from the Spanish Government, CTQ2013-41507-R and CNPq (Brazil). The predoctoral fellowships for Ms. García-Galán (Spanish Government), Mr K. Hernandez (I3P-CSIC) and $\mathrm{Mr}$ dos Santos (CNPq, Brazil) are also recognized. ). Á. Berenguer-Murcia thanks the Spanish Ministerio de Ciencia e Innovacion for a Ramon y Cajal fellowship (RyC-200903813). The authors wish to thank Mr. Ramiro Martínez (Novozymes, Spain) for his continuous support to our research.

\section{REFERENCES}

[1] Dicosimo, R.; McAuliffe, J.; Poulose, A.J.; Bohlmann, G. Industrial use of immobilized enzymes. Chem. Soc. Rev., 2013, 42, 6437-6474.

[2] Homaei, A.A.; Sariri, R.; Vianello, F.; Stevanato, R. Enzyme immobilization: An update. J. Chem. Biol., 2013, 6, 185-205.

[3] Liese, A.; Hilterhaus, L. Evaluation of immobilized enzymes for industrial applications. Chem. Soc. Rev., 2013, 42, 6236-6249.

[4] Garcia-Galan, C.; Berenguer-Murcia, A.; Fernandez-Lafuente, R.; Rodrigues, R.C. Potential of different enzyme immobilization strategies to improve enzyme performance. Adv. Synth. Catal., 2011, 353, 2885-2904.

[5] Mateo, C.; Palomo, J.M.; Fernandez-Lorente, G.; Guisan, J.M.; FernandezLafuente, R. Improvement of enzyme activity, stability and selectivity via immobilization techniques. Enzyme Microb. Technol., 2007, 40, 1451-1463.

[6] Rodrigues, R.C.; Ortiz, C.; Berenguer-Murcia, A.; Torres, R.; FernandezLafuente, R. Modifying enzyme activity and selectivity by immobilization. Chem. Soc. Rev., 2013, 45, 6290-6307.

[7] Mateo, C.; Abian, O.; Bernedo, M.; Cuenca, E.; Fuentes, M.; FernandezLorente, G.; Palomo, J.M.; Grazu, V.; Pessela, B.C.C.; Giacomini, C. Some special features of glyoxyl supports to immobilize proteins. Enzyme Microb. Technol., 2005, 37, 456-462.

[8] Mateo, C.; Palomo, J.M.; Fuentes, M.; Betancor, L.; Grazu, V.; LópezGallego, F.; Pessela, B.C.C.; Hidalgo, A.; Fernández-Lorente, G.; FernándezLafuente, R. Glyoxyl agarose: A fully inert and hydrophilic support for immobilization and high stabilization of proteins. Enzyme Microb. Technol., 2006, 39, 274-280

[9] Mateo, C.; Abian, O.; Fernandez-Lafuente, R.; Guisan, J.M. Reversible enzyme immobilization via a very strong and nondistorting ionic adsorption on support-polyethylenimine composites. Biotechnol. Bioeng., 2000, 68, 98105.

[10] Séverac, E.; Galy, O.; Turon, F.; Pantel, C.A.; Condoret, J.S.; Monsan, P.; Marty, A. Selection of CalB immobilization method to be used in continuous oil transesterification: Analysis of the economical impact. Enzyme Microb. Technol., 2011, 48, 61-70.

[11] Martins, A.B.; Graebin, N.G.; Lorenzoni, A.S.G.; Fernandez-Lafuente, R.; Ayub, M.A.Z.; Rodrigues, R.C. Rapid and high yields of synthesis of butyl acetate catalyzed by Novozym 435: Reaction optimization by response surface methodology. Process Biochem., 2011, 46, 2311-2316.

[12] Rodrigues, R.C.; Volpato, G.; Wada, K.; Ayub, M.A.Z. Enzymatic synthesis of biodiesel from transesterification reactions of vegetable oils and short chain alcohols. J. Am. Oil Chem. Soc., 2008, 85, 925-930.

[13] Graebin, N.G.; Martins, A.B.; Lorenzoni, A.S.G.; Garcia-Galan, C.; Fernandez-Lafuente, R.; Ayub, M.A.Z.; Rodrigues, R.C. Immobilization of lipase B from Candida antarctica on porous styrene-divinylbenzene beads improves butyl acetate synthesis. Biotechnol. Prog., 2012, 28, 406-412.

[14] Hernandez, K.; Berenguer-Murcia, A.; Rodrigues, R.C.; Fernandez-Lafuente, R. Hydrogen peroxide in biocatalysis. A dangerous liaison. Curr. Org. Chem., 2012, 16, 2652-2672.

[15] Bartling, G.J.; Chattopadhyay, S.K.; Brown, H.D. A convenient new method of enzyme immobilization. Biotechnol. Bioeng., 1974, 16, 1425-1429.

[16] Md. Zin Wan Yunus, W.; Salleh, A.B.; Basri, M.; Ampon, K.; Abd. Razak, C.N. Preparation and immobilization of lipase on to poly(methyl acrylatemethyl methacrylate-divinylbenzene) beads far lipid hydrolysis. Biotechnol. Appl. Biochem., 1996, 24, 19-23.

[17] Tai, Y.; Wang, L.; Gao, J.; Tao, W.; Huo, J.; Yang, L. Synthesis of core/shell magnetic porous microspheres for lipase immobilization. J. Inorg. Organomet. Polym. Mater., 2012, 22, 213-222.

[18] Rajasekar, V.W.; Tambe, A.; Datla, A. Immobilization and characterization of recombinant Candida antarctica lipase B on poly(glycidyl methacrylateter-divinyl benzene-ter-ethylene dimethacrylate) beads, DILBEADSTMTA. Biocatal. Biotransform., 2013, 31, 79-88.

[19] Xiong, C.; Zhou, X.; Zhang, N.; Zhan, L.; Chen, S.; Wang, J.; Peng, W.P.; Chang, H.C.; Nie, Z. Quantitative assessment of protein adsorption on microparticles with particle mass spectrometry. Anal. Chem., 2014, 86, 38763881

[20] Petr, Š.; Daniel, H.; Michal, B. PEG-modified magnetic hypercrosslinked poly(styrene-co-divinylbenzene) microspheres to minimize sorption of serum proteins. React. Funct. Polym., 2013, 73, 1122-1129.

[21] Kumar, G.S.V.; Kumar, K.S. Immobilization of catalase on a novel polymer support, crosslinked polystyrene ethylene glycol acrylate resin: Role of the macromolecular matrix on enzyme activity. J. Appl. Polym. Sci., 2005, 97, 819

[22] Jayakumari, V.G.; Pillai, V.N.R. Peptide synthesis catalysed by papain immobilised on polymer supports: Effect of the macromolecular structure and reaction conditions on synthesis. Proc. Indian Acad. Sci. (Chem. Sci.), 1991, 103, 133-148.

[23] Barbosa, O; Ortiz, C; Berenguer-Murcia, A.; Torres, R; Rodrigues, R.C. Fernandez-Lafuente, R. Glutaraldehyde in bio-catalysts design: A useful crosslinker and a versatile tool in enzyme immobilization. RSC Advances, 2014, 4, 1583-1600.

[24] Hasan, F.; Shah, A.A.; Hameed, A. Industrial applications of microbial lipases. Enzyme Microb. Technol., 2006, 39, 235-251.

[25] Nagarajan, S. New tools for exploring old friends-microbial lipases. Appl. Biochem. Biotechnol., 2012, 168, 1163-1196.

[26] Fernandez-Lafuente, R. Lipase from Thermomyces lanuginosus: Uses and prospects as an industrial biocatalyst. J. Mol. Catal. B: Enzym., 2010, 62, 197-212.

[27] Dizge, N.; Keskinler, B.; Tanriseven, A. Covalent attachment of microbial lipase onto microporous styrene-divinylbenzene copolymer by means of polyglutaraldehyde. Colloids Surf., B, 2008, 66, 34-38.

[28] Dizge, N.; Keskinler, B.; Tanriseven, A. Biodiesel production from canola oil by using lipase immobilized onto hydrophobic microporous styrenedivinylbenzene copolymer. Biochem. Eng. J., 2009, 44, 220-225.

[29] Dizge, N.; Aydiner, C.; Imer, D.Y; Bayramoglu, M.; Tanriseven, A. Keskinler, B. Biodiesel production from sunflower, soybean, and waste cooking oils by transesterification using lipase immobilized onto a novel microporous polymer. Bioresour. Technol., 2009, 100, 1983-1991.

[30] Aybastier, T.; Demir, C. Optimization of immobilization conditions of Thermomyces lanuginosus lipase on styrene-divinylbenzene copolymer using response surface methodology. J. Mol. Catal. B: Enzym., 2010, 63, 170-178.

[31] Yücel, Y.; Demir, C.; Dizge, N.; Keskinler, B. Lipase immobilization an production of fatty acid methyl esters from canola oil using immobilized lipase. Biomass Bioenergy, 2011, 35, 1496-1501.

[32] Yücel, Y. The enzymatic production of biodiesel from pomace oil using immobilized Thermomyces lanuginosus. Energy Sources Recovery Util. Environ. Eff., 2013, 35, 370-375.

[33] Rodrigues, R.C.; Fernandez-Lafuente, R. Lipase from Rhizomucor miehei as a biocatalyst in fats and oils modification. J. Mol. Catal. B: Enzym., 2010, 66, 15-32.

[34] Rodrigues, R.C.; Fernandez-Lafuente, R. Lipase from Rhizomucor miehei as an industrial biocatalyst in chemical process. J. Mol. Catal. B: Enzym., 2010 64, 1-22.

[35] Karagoz, B.; Bayramoglu, G.; Altintas, B.; Bicak, N.; Arica, M.Y. Poly(glycidyl methacrylate)-polystyrene diblocks copolymer grafted nanocomposite microspheres from surface-initiated atom transfer radical polymerization for lipase immobilization: Application in flavor ester synthesis. Ind. Eng. Chem. Res., 2010, 49, 9655-9665.

[36] Ahin, S.; Demir, C.; Malyer, H. Determination of total phenolic content of Prunella L. by immobilized enzyme bioreactor. Anal. Methods, 2011, 3, 944 950 .

[37] Villegas-Rosas, M.L.O.; Geissler, G.; Handal-Silva, A.; González-Vergara, E. Immobilization of a peroxidase from chayote [Sechium edule (Jacq.) SW] and its potential application in the removal of phenolic substances from waste waters. Rev. Int. Contam. Ambient., 2003, 19, 73-81.

[38] Ozoner, S.K.; Keskinler, B.; Erhan, E. HRP immobilized microporous poly(styrene-divinylbenzene-polyglutaraldehyde) monolith for forced flow injected phenol biosensing. Mater. Sci. Eng., C 2011, 31, 663-668.

[39] Ișik, E.; Şahin, S.; Demir, C.; Türkben, C. Determination of total phenolic content of raspberry and blackberry cultivars by immobilized horseradish peroxidase bioreactor. J. Food Compos. Anal., 2011, 24, 944-949.

[40] Davidenko, T.I.; Koshelev, S.A.; Makarova, S.B. Immobilization of urease on modified styrene/polyvinylbenzene matrices. Chem. Nat. Compd., 1986, 22, 587-592.

[41] Fernandez-Lafuente, R. Stabilization of multimeric enzymes: Strategies to prevent subunit dissociation. Enzyme Microb. Technol., 2009, 45, 405-418.

[42] Ulbrich-Hofmann, R.; Selisko, B. Soluble and immobilized enzymes in water-miscible organic solvents: Glucoamylase and invertase. Enzyme Microb. Technol., 1993, 15, 33-41.

[43] Marek, M.; Valentova, O.; Kas, J. Invertase immobilization via its carbohydrate moiety. Biotechnol. Bioeng., 1984, 26, 1223-1226.

[44] Hasegawa, M.; Kitano, H.; Nishida, R.; Kobashi, T. Macroporous and hydrophilic polymer resins modified with isothiocyanate groups for immobilization of enzymes. Biotechnol. Bioeng., 1990, 36, 219-223.

[45] Kondo, A.; Fukuda, H. Preparation of thermo-sensitive magnetic microspheres and their application to bioprocesses. Colloids Surf. A Physicochem. Eng. Asp., 1999, 153, 435-438.

[46] Fuentes, M.; Pessela, B.C.C.; Maquiese, J.V.; Ortiz, C.; Segura, R.L.; Palomo, J.M.; Abian, O.; Torres, R.; Mateo, C.; Fernández-Lafuente, R. Reversible and strong immobilization of proteins by ionic exchange on supports coated with sulfate-dextran. Biotechnol. Prog., 2004, 20, 11341139 .

[47] Torres, R.; Mateo, C.; Fernández-Lorente, G.; Ortiz, C.; Fuentes, M.; Palomo, J.M.; Guisan, J.M.; Fernández-Lafuente, R. A novel heterofunctional epoxy-amino sepabeads for a new enzyme immobilization 
protocol: Immobilization-stabilization of $\beta$-galactosidase from Aspergillus oryzae. Biotechnol. Prog., 2003, 19, 1056-1060.

[48] Fernandez-Lafuente, R.; Armisén, P.; Sabuquillo, P.; Fernández-Lorente, G.; Guisán, J.M. Immobilization of lipases by selective adsorption on hydrophobic supports. Chem. Phys. Lipids, 1998, 93, 185-197.

[49] Bolivar, J.M.; Rocha-Martin, J.; Godoy, C.; Rodrigues, R.C.; Guisan, J.M. Complete reactivation of immobilized derivatives of a trimeric glutamate dehydrogenase from Thermus thermophillus. Process Biochem., 2010, 45, 107-113.

[50] Rodrigues, R.C.; Bolivar, J.M.; Palau-Ors, A.; Volpato, G.; Ayub, M.A.Z.; Fernandez-Lafuente, R.; Guisan, J.M. Positive effects of the multipoint covalent immobilization in the reactivation of partially inactivated derivatives of lipase from Thermomyces lanuginosus. Enzyme Microb. Technol., 2009, 44, 386-393.

[51] Rodrigues, R.C.; Bolivar, J.M.; Volpato, G.; Filice, M.; Godoy, C.; Fernandez-Lafuente, R.; Guisan, J.M. Improved reactivation of immobilizedstabilized lipase from Thermomyces lanuginosus by its coating with highly hydrophilic polymers. J. Biotechnol., 2009, 144, 113-119.

[52] Rodrigues, R.C.; Godoy, C.A.; Filice, M.; Bolivar, J.M.; Palau-Ors, A.; Garcia-Vargas, J.M.; Romero, O.; Wilson, L.; Ayub, M.A.Z.; FernandezLafuente, R. Reactivation of covalently immobilized lipase from Thermomyces lanuginosus. Process Biochem., 2009, 44, 641-646.

[53] Cook, B.C. Reactivity of human platelets with immobilized fibrinogen is dictated by the chemical character of the surface. Thromb. Res., 2001, 104, $39-48$.

[54] Lothe, R.R.; Purohit, S.S.; Shaikh, S.S.; Malshe, V.C.; Pandit, A.B. Purification of $\alpha$-glucosidae and invertase from bakers' yeast on modified polymeric supports. Bioseparation, 1999, 8, 293-306.

[55] Agrawal, P.B.; Pandit, A.B. Isolation of $\alpha$-glucosidase from Saccharomyces cerevisiae: Cell disruption and adsorption. Biochem. Eng. J., 2003, 15, 37 45

[56] Ruckenstein, E.; Wang, X.B. Production of lignin peroxidase by Phanerochaete chrysosporium immobilized on porous poly(styrenedivinylbenzene) carrier and its application to the degrading of 2chlorophenol. Biotechnol. Bioeng., 1994, 44, 79-86.

[57] Makarova, S.B.; Gryaznov, G.V.; Litvak, Z.M.; Prosvetova, N.K.; Mendel'son, Y.A.; Shabanova, N.V.; Kim, G.I. Haloacetyl derivatives of styrene-divinylbenzene copolymers as carriers for the immobilization of enzymes. Polymer Science U.S.S.R., 1980, 22, 873-878.

[58] Crapisi, A.; Lante, A.; Pasini, G.; Spettoli, P. Enhanced microbial cell lysis by the use of lysozyme immobilized on different carriers. Process Biochem., 1994, 28, 17-21.

[59] Poźniak, G.; Turkiewicz, B.; Rucka, M.; Zboińska, E. Optimization of enzyme immobilization on interpolymer membranes. Environ. Prot. Eng., 2005, 31, 221-228.

[60] Zhou, Z.; Yang, Y.; Zhang, J.; Zhang, Z.; Bai, Y.; Liao, Y.; Liu, H. Ionexchange-membrane-based enzyme micro-reactor coupled online with liquid chromatography-mass spectrometry for protein analysis. Anal. Bioanal. Chem., 2012, 403, 239-246.

[61] Ince, A.; Bayramoglu, G.; Karagoz, B.; Altintas, B.; Bicak, N.; Arica, M.Y. A method for fabrication of polyaniline coated polymer microspheres and its application for cellulase immobilization. Chem. Eng. J., 2012, 189-190, 404412.

[62] Dupont, J.; De Souza, R.F.; Suarez, P.A.Z. Ionic liquid (molten salt) phase organometallic catalysis. Chem. Rev., 2002, 102, 3667-3692.

[63] Poole, C.F. Chromatographic and spectroscopic methods for the determination of solvent properties of room temperature ionic liquids. $J$. Chromatogr. A, 2004, 1037, 49-82.

[64] Reichardt, C. Polarity of ionic liquids determined empirically by means of solvatochromic pyridinium N-phenolate betaine dyes. Green Chem., 2005, 7, 339-351.

[65] Garcia, M.T.; Gathergood, N.; Scammells, P.J. Biodegradable ionic liquids Part II. Effect of the anion and toxicology. Green Chem., 2005, 7, 9-14.

[66] Docherty, K.M.; Kulpa Jr, C.F. Toxicity and antimicrobial activity of imidazolium and pyridinium ionic liquids. Green Chem., 2005, 7, 185-189.

[67] Pretti, C.; Chiappe, C.; Pieraccini, D.; Gregori, M.; Abramo, F.; Monni, G.; Intorre, L. Acute toxicity of ionic liquids to the zebrafish (Danio rerio). Green Chem., 2006, 8, 238-240.

[68] Valkenberg, M.H.; DeCastro, C.; Hölderich, W.F. Immobilisation of ionic liquids on solid supports. Green Chem., 2002, 4, 88-93.

[69] Fonseca, G.S.; Scholten, J.D.; Dupont, J. Iridium nanoparticles prepared in ionic liquids: An efficient catalytic system for the hydrogenation of ketones. Synlett, 2004, 1525-1528.

[70] Gadenne, B.; Hesemann, P.; Moreau, J.J.E. Supported ionic liquids: Ordered mesoporous silicas containing covalently linked ionic species. Chem. Commun., 2004, 10, 1768-1769.

[71] Mehnert, C.P. Supported ionic liquid catalysis. Chem. Eur. J., 2005, 11, 5056

[72] Izquierdo, D.F.; Bernal, J.M.; Burguete, M.I.; García-Verdugo, E.; Lozano, P.; Luis, S.V. An efficient microwave-assisted enzymatic resolution of alcohols using a lipase immobilised on supported ionic liquid-like phases (SILLPs). RSC Advances, 2013, 3, 13123-13126.

[73] Lee, J.K.; Kim, M.J. Ionic liquid-coated enzyme for biocatalysis in organic solvent. J. Org. Chem., 2002, 67, 6845-6847.
[74] Itoh, T.; Matsushita, Y.; Abe, Y.; Han, S.H.; Wada, S.; Hayase, S Kawatsura, M.; Takai, S.; Morimoto, M.; Hirose, Y. Increased enantioselectivity and remarkable acceleration of lipase-catalyzed transesterification by using an imidazolium PEG-Alkyl sulfate ionic liquid. Chem. Eur. J., 2006, 12, 9228-9237.

[75] Lozano, P.; De Diego, T.; Sauer, T.; Vaultier, M.; Gmouh, S.; Iborra, J.L. On the importance of the supporting material for activity of immobilized Candida antarctica lipase $\mathrm{B}$ in ionic liquid/hexane and ionic liquid/supercritical carbon dioxide biphasic media., J. Supercrit. Fluids, 2007, 40, 93-100.

[76] Lozano, P.; de Diego, T.; Carrié, D.; Vaultier, M. Iborra, J.L. Lipase catalysis in ionic liquids and supercritical carbon dioxide at $150{ }^{\circ} \mathrm{C}$ Biotechnol. Prog., 2003, 19, 380-382.

[77] Lozano, P.; García-Verdugo, E.; Piamtongkam, R.; Karbass, N.; De Diego, T.; Burguete, M.I.; Luis, S.V.; Iborra, J.L. Bioreactors based on monolithsupported ionic liquid phase for enzyme catalysis in supercritical carbon dioxide. Adv. Synth. Cat., 2007, 349, 1077-1084

[78] Sans, V.; Karbass, N.; Burguete, M.I.; Compañ, V.; García-Verdugo, E.; Luis, S.V.; Pawlak, M. Polymer-supported ionic-liquid-like phases (SILLPs) Transferring ionic liquid properties to polymeric matrices. Chem. Eur. J., 2011, 17, 1894-1906.

[79] Lozano, P.; García-Verdugo, E.; Bernal, J.M.; Izquierdo, D.F.; Burguete M.I.; Sánchez-Gómez, G.; Luis, S.V. Immobilised lipase on structured supports containing covalently attached ionic liquids for the continuous synthesis of biodiesel in $\mathrm{ScCO}_{2}$. ChemSusChem, 2012, 5, 790-798.

[80] Miled, N.; Beisson, F.; De Caro, J.; De Caro, A.; Arondel, V.; Verger, R. Interfacial catalysis by lipases. J. Mol. Catal. B: Enzym., 2001, 11, 165-171.

[81] Verger, R. 'Interfacial activation' of lipases: Facts and artifacts. Trends Biotechnol., 1997, 15, 32-38.

[82] Berg, O.G.; Cajal, Y.; Butterfoss, G.L.; Grey, R.L.; Alsina, M.A.; Yu, B.Z.; Jain, M.K. Interfacial activation of triglyceride lipase from Thermomyce (Humicola) lanuginosa: Kinetic parameters and a basis for control of the lid. Biochemistry, 1998, 37, 6615-6627.

[83] Brzozowski, A.M.; Savage, H.; Verma, C.S.; Turkenburg, J.P.; Lawson, D.M.; Svendsen, A.; Patkar, S. Structural origins of the interfacial activation in Thermomyces (Humicola) lanuginosa lipase. Biochemistry, 2000, 39, 15071-15082.

[84] Uppenberg, J.; Patkar, S.; Bergfors, T.; Jones, T.A. Crystallization and preliminary X-ray studies of lipase B from Candida antarctica. J. Mol. Biol., 1994, 235, 790-792.

[85] Carrasco-López, C.; Godoy, C.; De las Rivas, B.; Fernández-Lorente, G.; Palomo, J.M.; Guisán, J.M.; Fernández-Lafuente, R.; Martínez-Ripoll, M. Hermoso, J.A. Activation of bacterial thermo alkalophilic lipases is spurred by dramatic structural rearrangements. J. Biol. Chem., 2009, 284, 4365-4372.

[86] Bastida, A.; Sabuquillo, P.; Armisen, P.; Fernández-Lafuente, R.; Huguet, J. Guisán, J.M. A single step purification, immobilization, and hyperactivation of lipases via interfacial adsorption on strongly hydrophobic supports. Biotechnol. Bioeng., 1998, 58, 486-493.

[87] Fernandez-Lorente, G.; Cabrera, Z.; Godoy, C.; Fernandez-Lafuente, R.; Palomo, J.M.; Guisan, J.M. Interfacially activated lipases against hydrophobic supports: Effect of the support nature on the biocatalytic properties. Process Biochem., 2008, 43, 1061-1067.

[88] Ruckenstein, E.; Wang, X. Lipase immobilized on hydrophobic porou polymer supports prepared by concentrated emulsion polymerization and their activity in the hydrolysis of triacylglycerides. Biotechnol. Bioeng., 1993, 42, 821-828

[89] Ruckenstein, E.; Wang, X. A novel support for the immobilization of lipase and the effects of the details of its preparation on the hydrolysis of triacylglycerides. Biotechnol. Tech., 1993, 7, 117-122.

[90] De Oliveira, P.C.; Alves, G.M.; De Castro, H.F. Immobilisation studies and catalytic properties of microbial lipase onto styrene-divinylbenzene copolymer. Biochem. Eng. J., 2000, 5, 63-71.

[91] Huang, F.C.; Ke, C.H.; Kao, C.Y.; Lee, W.C. Preparation and application of partially porous poly(styrene-divinylbenzene) particles for lipase immobilization. J. Appl. Polym. Sci., 2001, 80, 39-46.

[92] Kao, C.Y.; Lo, T.C.; Lee, W.C. Influence of polyvinylpyrrolidone on the hydrophobic properties of partially porous poly(styrene-divinylbenzene) particles for biological applications. J. Appl. Polym. Sci., 2003, 87, 18181824.

[93] Bussamara, R.; Dall'Agnol, L.; Schrank, A.; Fernandes, K.F.; Vainstein, M.H. Optimal conditions for continuous immobilization of Pseudozyma hubeiensis (Strain HB85A) lipase by adsorption in a packed-bed reactor by response surface methodology. Enzyme Res., 2012, 2012.

[94] Hernandez, K.; Garcia-Galan, C.; Fernandez-Lafuente, R. Simple and efficient immobilization of lipase B from Candida antarctica on porou styrene-divinylbenzene beads. Enzyme Microb. Technol., 2011, 49, 72-78.

[95] Palomo, J.M.; Muoz, G.; Fernández-Lorente, G.; Mateo, C.; FernándezLafuente, R.; Guisán, J.M. Interfacial adsorption of lipases on very hydrophobic support (octadecyl-Sepabeads): Immobilization, hyperactivation and stabilization of the open form of lipases. J. Mol. Catal. B: Enzym., 2002 19-20, 279-286

[96] Garcia-Galan, C.; Barbosa, O.; Hernandez, K.; Santos, J.; Rodrigues, R.; Fernandez-Lafuente, R. Evaluation of styrene-divinylbenzene beads as a support to immobilize lipases. Molecules, 2014, 19, 7629-7645. 
[97] Balat, M.; Balat, H. Progress in biodiesel processing. Appl. Energy, 2010, 87, 1815-1835.

[98] Bajaj, A.; Lohan, P.; Jha, P.N.; Mehrotra, R. Biodiesel production through lipase catalyzed transesterification: An overview. J. Mol. Catal. B: Enzym., 2010, 62, 9-14.

[99] Poppe, J.K.; Garcia-Galan, C.; Matte, C.R.; Fernandez-Lafuente, R.; Rodrigues, R.C.; Ayub, M.A.Z. Optimization of synthesis of fatty acid methyl esters catalyzed by lipase B from Candida antarctica immobilized in hydrophobic supports. J. Mol. Catal. B: Enzym., 2013, 94, 51-56.

[100] De Oliveira, P.C.; Alves, G.M.; De Castro, H.F.; Innocentini Mei, L.H. Synthesis of butyl butyrate by microbial lipase immobilized onto styrenedivinylbenzene copolymer. Quim. Nova, 2000, 23, 632-636.

[101] Santos, J.C.; De Castro, H.F. Optimization of lipase-catalysed synthesis of butyl butyrate using a factorial design. World J. Microbiol. Biotechnol., 2006, 22, 1007-1011.

[102] Santos, J.C.; Bueno, T.; Molgero da Rós, P.C.; De Castro, H.F. Lipasecatalyzed synthesis of butyl esters by direct esterification in solvent-free system. J. Chem. Technol. Biotechnol., 2007, 82, 956-961.

[103] Bayramoglu, G.; Karagoz, B.; Altintas, B.; Yakup Arica, M.; Bicak, N. Poly(styrene-divinylbenzene) beads surface functionalized with di-block polymer grafting and multi-modal ligand attachment: Performance of reversibly immobilized lipase in ester synthesis. Bioprocess Biosyst. Eng., 2011, 34, 735-746.

[104] Fu, D.; Cai, H.; Zhou, X.; Qin, P.; Tan, T. Preparation of a macroporous hydrophobic poly(styrene-divinylbenzene) support and its application in lipase immobilization. Beijing Huagong Daxue Xuebao, 2010, 37, 116-120.

[105] Friedrich, J.L.R.; Peña, F.P.; Garcia-Galan, C.; Fernandez-Lafuente, R.; Ayub, M.A.Z.; Rodrigues, R.C. Effect of immobilization protocol on optimal conditions of ethyl butyrate synthesis catalyzed by lipase B from Candida antarctica. J. Chem. Technol. Biotechnol., 2013, 88, 1089-1095.
[106] Martins, A.B.; Friedrich, J.L.R.; Cavalheiro, J.C.; Garcia-Galan, C.; Barbosa, O.; Ayub, M.A.Z.; Fernandez-Lafuente, R.; Rodrigues, R.C. Improved production of butyl butyrate with lipase from Thermomyces lanuginosus immobilized on styrene-divinylbenzene beads. Bioresour. Technol., 2013 134, 417-422.

[107] De Abreu, L.; Fernandez-Lafuente, R.; Rodrigues, R.C.; Volpato, G.; Ayub, M.A.Z. Efficient purification-immobilization of an organic solvent-tolerant lipase from Staphylococcus warneri EX17 on porous styrene-divinylbenzene beads. J. Mol. Catal. B: Enzym., 2014, 99, 51-55.

[108] Hult, K.; Berglund, P. Enzyme promiscuity: Mechanism and applications. Trends Biotechnol., 2007, 25, 231-238.

[109] Hernandez, K.; Fernandez-Lafuente, R. Lipase B from Candida antarctica immobilized on octadecyl Sepabeads: A very stable biocatalyst in the presence of hydrogen peroxide. Process Biochem., 2011, 46, 873-878.

[110] Izquierdo, D.F.; Barbosa, O.; Burguete, M.I.; Lozano, P.; Luis, S.V.; Fernandez-Lafuente, R.; Garcia-Verdugo, E. Tuning lipase B from Candida antarctica $\mathrm{C}-\mathrm{C}$ bond promiscuous activity by immobilization on polystyrene-divinylbenzene beads. RSC Adv., 2014, 4, 6219-6225.

[111] Fexby, S.; Bülow, L. Hydrophobic peptide tags as tools in bioseparation. Trends Biotechnol., 2004, 22, 511-516.

[112] Costa, S.J.; Coelho, E.; Franco, L.; Almeida, A.; Castro, A.; Domingues, L. The Fh8 tag: A fusion partner for simple and cost-effective protein purification in Escherichia coli. Protein Expr. Purif., 2013, 92, 163-170.

[113] Lienqueo, M.E.; Salazar, O.; Calado, C.R.C.; Fonseca, L.P.; Cabral, J.M.S Influence of tryptophan tags on the purification of cutinase, secreted by a recombinant Saccharomyces cerevisiae, using cationic expanded bed adsorption and hydrophobic interaction chromatography. Biotechnol. Lett., 2008, 30, 1353-1358. 